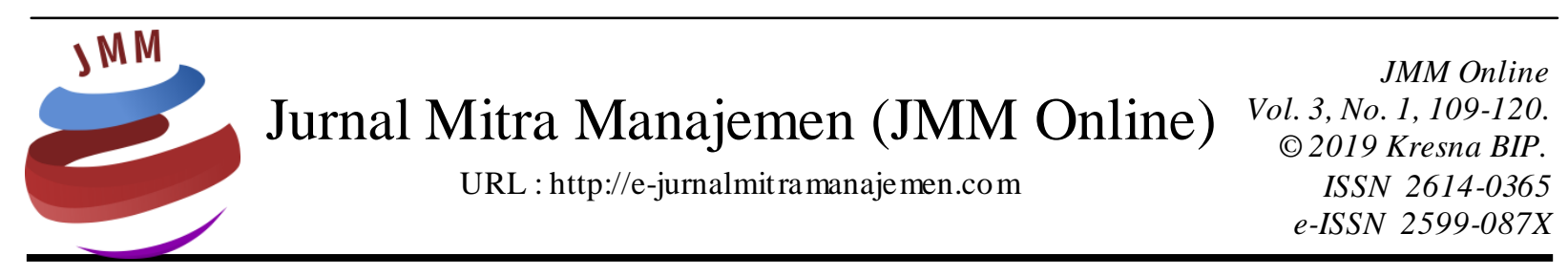

\title{
ANALISIS PERBEDAAN TINGKAT LITERASI KEUANGAN DAN PERILAKU KEUANGAN MAHASIS WA DI UNIVERSITAS TELKOM
}

\author{
Siti Aliah ${ }^{1)}$, Astrie Krisnawati ${ }^{2)}$ \\ Universitas Telkom
}

INFORMASI ARTIKEL

Dikirim : 11 Januari 2019

Revisi pertama : 21 Januari 2019

Diterima : 26 Januari 2019

Tersedia online : 31 Januari 2019

Kata Kunci : Literasi Keuangan, Perilaku Keuangan, Mahasiswa

\section{Email :}

sitialiahs@student.telkomuniversity.ac.id ${ }^{1)}$, astriekrisnawati@telkomuniversity.ac.id ${ }^{2)}$

\section{ABSTRAK}

Penelitian ini bertujuan untuk mengetahui tingkat literasi keuangan dan perilaku keuangan mahasiswa di Universitas Telkom serta perbedaannya antara mahasiswa yang berasal dari program studi berbasis ekonomi dan non ekonomi. Penelitian ini adalah penelitian kuantitatif. Populasi dari penelitian ini adalah mahasiswa aktif di Universitas Telkom tahun 2018 yang berjumlah 28.740 mahasiswa. Sampel penelitian ini berjumlah 400 diambil dengan teknik probability sampling. Data dikumpulkan dengan menggunakan kuesioner. Uji validitas dan reabilitas digunakan pada variabel literasi keuangan dan perilaku keuangan. Analisis data menggunakan Analisis Statistik Deskriptif dan Uji Mann Whitney. Hasil penelitian ini menunjukkan bahwa terdapat perbedaan tingkat literasi keuangan mahasiswa yang berasal dari program studi berbasis ekonomi dan non ekonomi, dengan rata-rata lebih tinggi mahasiswa berbasis ekonomi. Serta tidak adanya perbedaan tingkat perilaku keuangan mahasiswa yang berasal dari program studi berbasis ekonomi dan non ekonomi. 


\section{PENDAHULUAN \\ Latar Belakang}

Populasi penduduk Indonesia pada tahun 2018 mencapai 265 juta jiwa, dengan populasi kategori usia produktif (14-64 tahun) yang sangat besar yaitu sebanyak 179,13 juta jiwa atau sebesar 67,6\% (Kata Data, 2018). Diantara jumlah penduduk usia produktif di Indonesia, terdapat generasi $\mathrm{Y}$ atau sering disebut dengan generasi milenial, dimana generasi tersebut adalah kelompok individu yang lahir diawal tahun 1980 hingga awal tahun 2000 (Horovitz, 2012). Dengan kata lain, generasi milenial tersebut yang saat ini berusia antara 19-39 tahun. Mahasiswa, early jober dan orang tua muda termasuk kedalam generasi milenial (Walidah, 2017). Penggunaan internet telah membuat generasi milenial menjadi sangat konsumtif (CNN Indonesia, 2018). Perilaku konsumtif dipengaruhi oleh beberapa faktor, satu diantaranya adalah literasi keuangan. Solihat dan Anarsik (2018) dalam penelitiannya mengemukakan bahwa literasi ekonomi memiliki pengaruh yang signifikan terhadap perilaku konsumtif mahasiswa. Literasi keuangan adalah kebutuhan dasar bagi setiap individu agar tehindar dari masalah tentang keuangan (Yushita, 2017).

Menurut Survei Nasional Literasi Keuangan yang dilakukan oleh Otoritas Jasa Keuangan pada 2016, bahwa 67,8\% masyarakat Indonesia menggunakan produk dan layanan keuangan namun hanya $29,7 \%$ masyarakat yang well literate atau mempunyai pengetahuan tentang lembaga jasa keuangan dan produk jasa keuangan serta mempunyai keterampilan dalam menggunakannya (Otoritas Jasa Keuangan, 2017). Visa (2012) juga melakukan survei mengenai tingkat literasi keuangan di berbagai negara, hasilnya menunjukkan bahwa Indonesia berada di peringkat ke-27 dari 28 negara dengan skor $27,7 \%$.

Penelitian terdahulu seperti yang dilakukan oleh Nababan dan Sadalia (2013), Margaretha dan Pambudhi (2015), dan Lestari (2015) mengemukakan bahwa literasi keuangan mahasiswa masih tergolong kedalam kategori rendah. Literasi keuangan dipengaruhi beberapa faktor, satu diantaranya adalah pembelajaran di perguruan tinggi. Widayati (2012) dalam penelitiannya menjelaskan bahwa pembelajaran di perguruan tinggi mempunyai pengaruh langsung positif signifikan terhadap literasi finansial. Literasi keuangan juga menurut Laily (2014) dan Sari (2015) memiliki pengaruh yang signifikan terhadap perilaku keuangan seorang individu.

Dapat diartikan bahwa semakin tinggi tingkat literasi keuangan maka semakin baik perilaku keuangannya. Di Universitas Telkom mahasiswa yang berasal dari program studi berbasis ekonomi mendapatkan pembelajaran mengenai ekonomi dan keuangan sedangkan mahasiswa yang berasal dari program studi berbasis non ekonomi tidak.

\section{Rumusan Masalah}

Menurut CNN Indonesia (2018) karena penggunaan internet, generasi milenial sekarang ini sangat konsumtif. Generasi milenial adalah generasi yang saat ini berumur 19 hingga 39 tahun, dimana mahasiswa di Universitas Telkom adalah salah satunya karena rata-rata umur mahasiswa aktif pada tahun 2018 di Universitas Telkom adalah 21 tahun. Perilaku konsumtif tersebut dipengaruhi oleh rendahnya tingkat literasi keuangan, dimana selaras dengan berbagai penelitian yang telah dilakukan yang 
menyatakan bahwa tingkat literasi mahasiswa di Indonesia memang masih tergolong dalam kategori rendah. Literasi keuangan dipengaruhi beberapa faktor, salah satunya adalah pembelajaran di perguruan tinggi dan akan mempengaruhi perilaku keuangan mahasiswa nantinya. Di Universitas Telkom, mahasiswa dari program studi berbasis ekonomi mendapatkan pembelajaran mengenai ekonomi dan keuangan sedangkan mahasiswa yang berasal dari program studi berbasis non ekonomi tidak. Dimana dapat diasumsikan akan terdapat perbedaan tingkat literasi keuangan antara mahasiswa yang mendapatkan pembelajaran mengenai ekonomi dan keuangan dengan mahasiswa yang tidak mendapatkan pembelajaran, yang nantinya akan mempengaruhi juga perilaku keuangannya.

\section{Tujuan Penelitian}

Berdasarkan rumusan masalah diatas, maka tujuan dalam penelitian ini adalah sebagai berikut.

1. Mengetahui apakah terdapat perbedaan tingkat literasi keuangan mahasiswa dari Program Studi berbasis ekonomi bisnis dan non-ekonomi bisnis di Universitas Telkom.

2. Mengetahui apakah terdapat perbedaan tingkat perilaku keuangan dari Program Studi berbasis ekonomi bisnis dan non-ekonomi bisnis di Universitas Telkom.

\section{KAJIAN PUSTAKA \\ Lite rasi Keuangan}

Menurut Otoritas Jasa Keuangan (2017) literasi keuangan adalah pengetahuan, keterampilan dan keyakinan yang dimiliki oleh seorang individu yang mempengaruhi sikap dan perilaku untuk meningkatkan kualitas pengambilan keputusan dan pengelolaan keuangan dalam rangka mencapai kesejahteraan.

Menurut Lusardi dan Mitchell (2014) mengatakan bahwa literasi keuangan adalah pegetahuan keuangan dan kemampuan seorang individu untuk mengaplikasikannya.

Dari kedua pendapat diatas, dapat disimpulkan bahwa literasi keuangan adalah pengetahuan keuangan yang dimiliki oleh seorang individu untuk pengambilan keputusan mengenai keuangan demi mencapai kesejahteraan.

\section{Aspek-Aspek Literasi Keuangan}

Literasi keuangan mencakup beberapa aspek dalam keuangan, diantaranya menurut penelitian Nababan dan Sadalia (2013) yaitu:

a. Pengetahuan Dasar mengenai Keuangan Pribadi

Konsep dari pengetahuan dasar mengenai keuangan pribadi yaitu pemahaman dasar seseorang tentang keuangan, seperti perhitungan bunga sederana, bunga majemuk, inflasi, opportunity cost, nilai waktu uang dan likuid itas aset.

b. Manajemen Uang

Manajemen uang yaitu mempelajari bagaimana seseorang mengelola keuangan pribadinya. 
c. Kredit dan Utang

Utang dan kredit yaitu pendanaan dimana seorang individu dapat mengkonsumsi barang dan jasa pada saat ini dan membayarnya di masa yang akan datang. Maka dari itu seorang individu harus memiliki pengetahuan yang cukup tentang faktor kelayakan kredit, pertimbangan dalam melakukan pinjaman, karakteristik kredit konsumen, bunga pinjaman, jangka waktu pinjaman, sumber utang atau kredit untuk menggunakan kredit dan utang secara bijaksana.

d. Tabungan dan Investasi

Tabungan adalah bagian dari pendapatan seorang individu yang tidak digunakan, sementara investasi adalah bagian dari tabungan yang digunakan untuk kegiaan ekonomi yang menguntungkan.

e. Manajemen Risiko

Menurut Dewi (2017:22) risiko diartikan sebagai kemungkinan timbulnya kerugian. Langkah-langkah dalam proses manajemen risiko meliputi: (1) Pengidentifikasian risiko, (2) Pengukuran risiko dan (3) Pengendalian risiko.

\section{Tingkat Literasi Keuangan}

Menurut Nababan dan Sadalia (2013) kategori tingkat literasi keuangan individu dibagi menjad i tiga kelompok, dimana pengkategorian tingkatan ini didasarkan pada persentase jawaban responden yang benar kemudian dibagi dengan jumlah seluruh pertanyaan yang digunakan untuk mengukur literasi keuangan seseorang. Berikut adalah tingkatan literasi keuangan menurut Nababan dan Sadalia (2013):

a. Rendah, dimana tingkat literasi keuangannya di bawah $60 \%$.

b. Sedang, dimana tingkat literasi keuangannya diantara $60 \%$ sampai dengan $80 \%$.

c. Tinggi, dimana tingkat literasi keuangannya diatas $80 \%$.

Nababan dan Sadalia (2013) juga mengkategorikan literasi keuangan berdasarkan median. Responden yang mempunyai tingkat literasi keuangan dibawah median dimasukkan kedalam kategori responden dengan tingkat literasi keuangan yang relatif rendah sedangkan responden yang mempunyai tingkat literasi keuangan diatas median termasuk kedalam kategori responden dengan tingkat literasi keuangan yang relatif tinggi.

\section{Perilaku Keuangan}

Perilaku keuangan menurut Nababan dan Sadalia (2013) yaitu bagaimana seseorang memperlakukan, mengelola, dan menggunakan sumberdaya keuangan yang dimilikinya.

Kholilah dan Iramani (2013) perilaku keuangan diartikan sebagai kemampuan seseorang dalam mengatur dana keuangan sehari-hari.

Dari beberapa pendapat diatas, dapat disimpulkan bahwa perilaku keuangan adalah cara individu mengatur serta mengelola keuangan pribadinya. 


\section{Indikator-Indikator Perilaku Keuangan}

Nababan dan Sadalia (2013) mengemukakan indikator-indikator perilaku keuangan adalah:

a. Membayar tagihan tepat waktu

b. Membuat anggaran pengeluaran dan belanja

c. Mencatat pengeluaran dan belanja (harian, bulanan dan lain-lain)

d. Menyediakan dana untuk penegluaran tidak terduga

e. Menabung secara periodik

f. Membandingkan harga antar toko atau swalayan atau supermarket sebelum memutuskan untuk melakukan pembelian.

\section{METODE PENELITIAN}

\section{Definisi Operasional}

Variabel yang ada dalam penelitian ini adalah:

a. Literasi Keuangan (Variabel Independen)

Variabel ini mencakup basic personal finance, manajemen uang, kredit dan utang, tabungan dan investasi serta mengenai risiko.

b. Perilaku Keuangan (Variabel Dependen)

Variabel ini berhubungan dengan bagaimana seseorang memperlakukan, mengelola, dan menggunakan sumber daya keuangan yang dimilikinya.

\section{Populasi dan Sampel}

Populasi dalam penelitian ini adalah mahasiswa akif di Universitas Telkom yang menurut Direktorat Sistem Informasi Universitas Telkom berjumlah 28.740 mahasiswa. ampel penelitian ini berjumlah 400 diambil dengan teknik probability sampling.

\section{Meode Analisis Data}

Metode yang digunakan dalam penelitian ini adalah analisis deskriptif dimana untuk melihat rata-rata, median dan standar deviasi. Untuk uji hipotesis, penelitian ini menggunakan uji Mann Whitney dikarenakan data yang digunakan adalah data nominal (kategori). Penelitian ini juga termasuk kedalam penelitian non parametrik, karena menurut uji normalitas menggunakan uji Kolmogorov Smirnov, bahwa nilai residualnya tidak berd istribusi normal.

\section{Tempat, Waktu dan Subjek Penelitian}

Penelitian ini dilakukan di Universitas Telkom, Bandung. Penelitian ini dimulai pada bulan April 2018 hingga Desember 2018 dengan subjek penelitian adalah mahasiswa aktif di Universitas Telkom pada tahun 2018 yang menurut Direktorat Sistem Informasi berjumlah 28.740 mahasiswa.

\section{HASIL PENELITIAN DAN PEMBAHASAN Analisis Deskriptif Data Penelitian}

Analisis Deskriptif digunakan dalam penelitian ini untuk mengetahui gambaran pengetahuan dan persepsi 400 orang responden terhadap Literasi Keuangan dan 
Perilaku Keuangan. Berikut ini adalah hasil tingkat literasi keuangan mahasiswa aktif di Universitas Telkom pada tahun 2018.

Tabel 1. Literasi Keuangan Mahasiswa Secara Keseluruhan

\begin{tabular}{|c|c|c|l|l|l|}
\hline $\mathbf{N}$ & $\begin{array}{c}\text { Minium } \\
(\boldsymbol{\%})\end{array}$ & $\begin{array}{c}\text { Maksimum } \\
(\boldsymbol{\%})\end{array}$ & $\begin{array}{c}\text { Rata-Rata } \\
(\boldsymbol{\%})\end{array}$ & Median (\%) & $\begin{array}{c}\text { Standar } \\
\text { Deviasi }\end{array}$ \\
\hline 400 & 7 & 78 & 43.44 & 44 & 15.140 \\
\hline
\end{tabular}

Sumber: Hasil Olahan Data Primer, 2018

Hasil penyebaran kuesioner kepada 400 orang mahasiswa aktif di universitas Telkom tahun 2018 dapat dilihat pada tabel. Nilai terendah adalah $7 \%$ sedangkan teringgi adalah $78 \%$. Hal ini berarti bahwa dari 27 pertanyaan, ada responden yang hanya bisa menjawab 2 pertanyaan dengan benar (7\%) dari 27 pertanyaan dan ada juga responden yang mampu menjawab 21 pertanyaan (78\%) dengan benar dari 27 pertanyaan yang diajukan namun tidak ada responden yang bisa menjawab seluruh pertanyaan dengan benar. Tabel 2 menunjukkan hasil penelitian untuk setiap butir pertanyaan:

Tabel 2. Persentase Responden yang Menja wab dengan Benar Setiap Pertanyaan

\begin{tabular}{|l|l|l|}
\hline \multirow{2}{*}{ Pertanyaan Literasi Ke uangan (X) } & \multicolumn{2}{c|}{ Persentase } \\
\cline { 2 - 3 } & $\begin{array}{c}\text { Program Studi } \\
\text { Non Ekonomi }\end{array}$ & $\begin{array}{c}\text { Program Studi } \\
\text { Ekonomi }\end{array}$ \\
\hline Basic Personal Finance & & \\
\hline Manfaat pengetahuan keuangan & $54 \%$ & $67 \%$ \\
\hline Kuliah sebagai bagian dari investasi & $54 \%$ & $65 \%$ \\
\hline Likuiditas suatu asset & $19 \%$ & $31 \%$ \\
\hline Perhitungan tingkat bunga sederhana & $40 \%$ & $54 \%$ \\
\hline $\begin{array}{l}\text { Pengaruh inflasi terhadap ke lompok masyarakat } \\
\text { tertentu }\end{array}$ & $21 \%$ & $40 \%$ \\
\hline Pengaruh inflasi terhadap daya beli & $37 \%$ & $62 \%$ \\
\hline Pengatahuan mengenai bunga majemuk & $14 \%$ & $28 \%$ \\
\hline Rata-rata untuk Basic Personal Finance & $34 \%$ & $39 \%$ \\
\hline Manajemen Uang & & \\
\hline $\begin{array}{l}\text { Faktor-faktor yang mempengaruhi pendapatan } \\
\text { seseorang }\end{array}$ & $54 \%$ & $54 \%$ \\
\hline Sumber pendapatan paling umum & $84 \%$ & $80 \%$ \\
\hline Instrumen yang berkaitan dengan penge luaran & $53 \%$ & $58 \%$ \\
\hline Pengeluaran tidak terduga & $42 \%$ & $45 \%$ \\
\hline Manfaat penganggaran & $32 \%$ & $47 \%$ \\
\hline Karakteristik ATM & $78 \%$ & $83 \%$ \\
\hline Rata-rata untuk Manajemen Uang & $57 \%$ & $61 \%$ \\
\hline Utang dan Kredit & & $61 \%$ \\
\hline Faktor-faktor yang mempengaruhi kelayakan kredit & $60 \%$ & $45 \%$ \\
\hline Biaya peminjaman & $28 \%$ & $63 \%$ \\
\hline $\begin{array}{l}\text { Faktor yang perlu dipertimbangkan dalam } \\
\text { meminjam uang }\end{array}$ & $52 \%$ & $40 \%$ \\
\hline Manfaat kartu kredit & $39 \%$ & $52 \%$ \\
\hline Rata-rata untuk Utang dan Kredit & $45 \%$ & \\
\hline
\end{tabular}




\section{Lanjutan Tabel 2. Persentase Responden yang Menjawab dengan Benar Setiap Pe rtanyaan}

\begin{tabular}{|l|l|l|}
\hline \multirow{2}{*}{ Pertanyaan Literasi Ke uangan (X) } & \multicolumn{2}{c|}{ Persentase } \\
\cline { 2 - 3 } & $\begin{array}{c}\text { Program Studi } \\
\text { Non Ekonomi }\end{array}$ & $\begin{array}{c}\text { Program Studi } \\
\text { Ekonomi }\end{array}$ \\
\hline Tabungan dan Investasi & & \\
\hline Lembaga yang menjamin simpanan di bank & $42 \%$ & $58 \%$ \\
\hline Besar dana maksimum yang dijamin oleh LPS & $14 \%$ & $12 \%$ \\
\hline Karakteristik deposito & $38 \%$ & $58 \%$ \\
\hline Lembaga yang menerbitkan sertifikat deposito & $49 \%$ & $83 \%$ \\
\hline Pengaruh suku bunga terhadap harga obligasi & $14 \%$ & $34 \%$ \\
\hline Strategi investasi & $23 \%$ & $35 \%$ \\
\hline Saham & $43 \%$ & $83 \%$ \\
\hline Rata-rata untuk Tabungan dan Investasi & $31 \%$ & $41 \%$ \\
\hline Manajemen Risiko & & \\
\hline Tujuan utama memiliki asuransi & $80 \%$ & $90 \%$ \\
\hline $\begin{array}{l}\text { Jangka waktu perlindungan anak yang dicakup } \\
\text { polis asuransi orang tua }\end{array}$ & $17 \%$ & $26 \%$ \\
\hline Kelompok masyarakat dengan risiko paling besar & $38 \%$ & $42 \%$ \\
\hline Rata-rata untuk Manajemen Risiko & $45 \%$ & $53 \%$ \\
\hline
\end{tabular}

Sumber: Hasil Penelitian, diolah (2018)

Hasil dari tabel 2 dapat dilihat persentase responden yang menjawab setiap butir pertanyaan dengan benar dan rata-rata jawaban yang benar untuk setiap dimensi literasi keuangan. Berdasarkan tabel tersebut maka tingkat literasi keuangan mahasiswa yang berasal dari program studi ekonomi paling rendah pada dimensi basic personal finance yaitu sebesar 39\% dan yang paling tinggi pada dimensi manajemen uang yaitu sebesar $61 \%$. Sedangkan pada mahasiswa dari program studi berbasis non ekonomi paling rendah pada dimensi tabungan dan investasi sebesar $31 \%$ dan paling tinggi pada dimensi manajemen uang yaitu $57 \%$.

Berikut ini adalah hasil tingkat literasi keuangan menurut program studi mahasiswa:

Tabel 3. Literasi Keuangan Mahasiswa dari Masing-Masing Program Studi

\begin{tabular}{|l|l|l|l|l|l|l|}
\hline $\begin{array}{c}\text { Jumlah } \\
\text { Mahasis wa }\end{array}$ & $\begin{array}{l}\text { Program } \\
\text { Studi }\end{array}$ & $\begin{array}{l}\text { Minimum } \\
(\boldsymbol{\%})\end{array}$ & $\begin{array}{c}\text { Maksimum } \\
(\mathbf{\%})\end{array}$ & $\begin{array}{c}\text { Rata- } \\
\text { Rata (\%) }\end{array}$ & $\begin{array}{c}\text { Median } \\
(\boldsymbol{\%})\end{array}$ & $\begin{array}{l}\text { Standar } \\
\text { Deviasi }\end{array}$ \\
\hline 128 & Ekonomi & 15 & 78 & 47.66 & 48 & 14.422 \\
\hline 272 & $\begin{array}{l}\text { Non } \\
\text { Ekonomi }\end{array}$ & 7 & 78 & 41,48 & 41 & 15.456 \\
\hline
\end{tabular}

Sumber: Hasil Penelitian, diolah (2018)

Responden yang berasal dari program studi berbasis ekonomi berjumlah 128 orang. Nilai terendah adalah $15 \%$ dan teringgi adalah $78 \%$. Responden yang berasal dari program studi berbasis non ekonomi berjumlah 272 orang. Nilai terendah adalah $7 \%$ sedangkan teringgi adalah $78 \%$.

Dari tabel 3 terlihat bahwa tingkat literasi keuangan mahasiswa dari program studi berbasis ekonomi dan non ekonomi berada dalam kategori rendah $(<60 \%)$ dengan nilai rata-rata lebih tinggi mahasiswa program studi berbasis ekonomi sebesar $47,66 \%$ sedangkan mahasiswa dari program studi berbasis non ekonomi sebesar $41,48 \%$. 
Berdasarkan hasil tersebut, posisi tingkat literasi keuangan mahasiswa dari program studi berbasis ekonomi dan non ekonomi dapat digambarkan pada garis kontinum sebagai berikut:

\section{Gambar 1. Garis Kontinum Tingkat Literasi Keuangan}

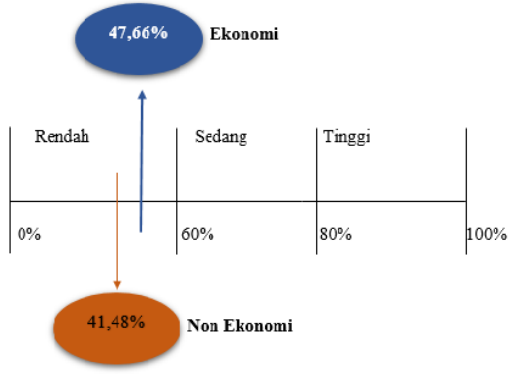

Sumber: Hasil Penelitian, diolah (2018)

\section{Hasil Penelitian Perilaku Keuangan Secara Keseluruhan}

Dalam penelitian ini, responden diberikan pertanyaan mengenai seberapa sering mereka melakukan perilaku-perilaku keuangan yang berkaitan dengan literasi keuangan (Nababan dan Sadalia, 2013). Metode ini merujuk pada penelitian sebelumnya dimana setiap pernyataan diberi skala berupa "tidak pernah", "jarang" dan "sering".

Berikut ini tabel frekuensi dari perilaku keuangan responden yang berkaitan dengan perilaku keuangan:

Tabel 4. Frekuensi Item-Item Perilaku Keuangan

\begin{tabular}{|l|c|c|c|c|c|c|}
\hline \multirow{2}{*}{$\begin{array}{c}\text { Dimensi Perilaku } \\
\text { Ke uangan }\end{array}$} & $\begin{array}{c}\text { Program Studi Non Ekonomi } \\
\text { Pernah } \\
(\%)\end{array}$ & $\begin{array}{c}\text { Jarang } \\
(\%)\end{array}$ & $\begin{array}{c}\text { Selalu } \\
(\%)\end{array}$ & $\begin{array}{c}\text { Program Studi Ekonomi } \\
\text { Pernah } \\
(\%)\end{array}$ & $\begin{array}{c}\text { Jarang } \\
(\%)\end{array}$ & $\begin{array}{c}\text { Selalu } \\
(\%)\end{array}$ \\
\hline $\begin{array}{l}\text { Membayar tagihan tepat } \\
\text { waktu (contoh: listrik, } \\
\text { pulsa pasca bayar, dan } \\
\text { lain-lain) }\end{array}$ & $\mathbf{6 \%}$ & $\mathbf{2 8 \%}$ & $\mathbf{6 6 \%}$ & $\mathbf{3 \%}$ & $\mathbf{3 0 \%}$ & $\mathbf{6 6 \%}$ \\
\hline $\begin{array}{l}\text { Membuat anggaran } \\
\text { pengeluaran dan belanja } \\
\text { (harian, bulanan, tahunan, } \\
\text { dan lain-lain) }\end{array}$ & $\mathbf{2 2 \%}$ & $\mathbf{5 6 \%}$ & $\mathbf{2 2 \%}$ & $\mathbf{2 2 \%}$ & $\mathbf{4 6 \%}$ & $\mathbf{3 2 \%}$ \\
\hline $\begin{array}{l}\text { Mencatat pengeluaran } \\
\text { (harian, bulanan dan lain- } \\
\text { lain) }\end{array}$ & $\mathbf{2 8 \%}$ & $\mathbf{5 1 \%}$ & $\mathbf{2 1 \%}$ & $\mathbf{3 0 \%}$ & $\mathbf{4 5 \%}$ & $\mathbf{2 5 \%}$ \\
\hline $\begin{array}{l}\text { Menyediakan dana untuk } \\
\text { pengeluaan tidak terduga }\end{array}$ & $\mathbf{1 3 \%}$ & $\mathbf{5 0 \%}$ & $\mathbf{3 8 \%}$ & $\mathbf{1 4 \%}$ & $\mathbf{5 3 \%}$ & $\mathbf{3 3 \%}$ \\
\hline Menabung secara rutin & $\mathbf{1 2 \%}$ & $\mathbf{5 5 \%}$ & $\mathbf{3 3 \%}$ & $\mathbf{7 \%}$ & $\mathbf{6 5 \%}$ & $\mathbf{2 8 \%}$ \\
\hline $\begin{array}{l}\text { Membandingkan arga antar } \\
\text { toko/swalayan/supermarket } \\
\text { sebelum memutuskan } \\
\text { untuk melakukan } \\
\text { pembelian }\end{array}$ & $\mathbf{8 \%}$ & $\mathbf{3 1 \%}$ & $\mathbf{6 1 \%}$ & $\mathbf{9 \%}$ & $\mathbf{3 0 \%}$ & $\mathbf{6 1 \%}$ \\
\hline
\end{tabular}

Sumber: Hasil Olahan Data Primer, 2018 
Berikut ini adalah hasil tingkat perilaku keuangan menurut program studi mahasiswa:

Tabel 5. Literasi Keuangan Mahasiswa dari Masing-Masing Program Studi

\begin{tabular}{|l|l|l|l|l|l|l|}
\hline $\begin{array}{c}\text { Jumlah } \\
\text { Mahasiswa }\end{array}$ & $\begin{array}{l}\text { Program } \\
\text { Studi }\end{array}$ & $\begin{array}{c}\text { Minium } \\
(\boldsymbol{\%})\end{array}$ & $\begin{array}{c}\text { Maksimum } \\
(\boldsymbol{\%})\end{array}$ & $\begin{array}{c}\text { Rata- } \\
\text { Rata }(\boldsymbol{\%})\end{array}$ & $\begin{array}{c}\text { Median } \\
(\boldsymbol{\%})\end{array}$ & $\begin{array}{l}\text { Standar } \\
\text { Deviasi }\end{array}$ \\
\hline 128 & Ekonomi & 39 & 100 & 75,64 & 78 & 12.909 \\
\hline 272 & $\begin{array}{l}\text { Non } \\
\text { Ekonomi }\end{array}$ & 33 & 100 & 75,09 & 72 & 13.460 \\
\hline
\end{tabular}

Sumber: Hasil Penelitian, diolah (2018)

Nilai terendah tingkat perilaku keuangan mahasiswa program studi ekonomi adalah 39\% dan teringgi adalah 100\%. Sedangkan untuk mahasiswa program studi non ekonomi bisnis nilai terendah berada di 33\% dengan nilai teringgi adalah $100 \%$.

Dari tabel 5 terlihat bahwa tingkat literasi keuangan mahasiswa dari program studi berbasis ekonomi dan non ekonomi berada dalam kategori baik. Berdasarkan hasil tersebut, posisi tingkat perilaku keuangan mahasiswa dari program studi berbasis ekonomi dan non ekonomi dapat digambarkan pada garis kontinum sebagai berikut:

\section{Gambar 2. Garis Kontinum Tingkat Pe rilaku Keuangan}

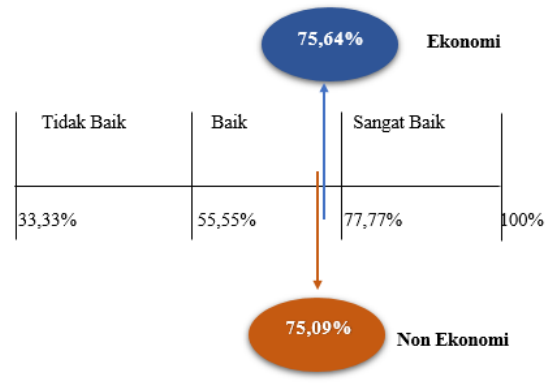

Sumber: Hasil Penelitian, diolah (2018)

\section{Hasil Uji Hipotesis}

Berdasarkan interpretasi hasil penelitian yang telah dilakukan, maka pada bagian ini akan dibahas lebih lanjut mengenai hipotesis penelitian. Penelitian ini dilakukan untuk mengetahui apakah terdapat perbedaan tingkat literasi keuangan dan juga tingkat perilaku keuangan mahasiswa dari program studi berbasis ekonomi dan non ekonomi. Dalam penelitian ini terdapat dua hipotesis untuk diuji.

Ada dua macam hipotesis tentang perbedaan tingkat literasi keuangan berdasarkan program studi mahasiswa. Hipotesis pertama adalah, $H_{0}$ : Tidak terdapat perbedaan tingkat literasi keuangan mahasiswa program studi berbasis ekonomi dan non ekonomi. Hipotesis kedua, $H_{l}$ : Terdapat perbedaan tingkat literasi keuangan mahasiswa program studi berbasis ekonomi dan non ekonomi. Hasil pengujian ditunjukkan pada Tabel 6, dimana tabel tersebut menunjukkan nilai signifikansi 0,002 < 0,005 hal ini menunjukkan terdapat perbedaan tingkat literasi keuangan mahasiswa program studi berbasis ekonomi dan non ekonomi. Dimana sesuai dengan hasil ana lisis statistic deskriptif yang menunjukkan bahwa tingkat literasi keuangan mahasiswa yang berasal dari program studi berbasis ekonomi lebih tinggi daripada mahasiswa yang berasal dari program studi berbasis non ekonomi. Hasil ini didukung oleh penelitian 
Widayati (2012) yang menjelaskan bahwa literasi keuangan mahasiswa dipengaruhi oleh pembelajaran di perguruan tinggi. Dimana dalam penelitian ini mahasiswa dari program studi berbasis ekonomi mendapatkan pembelajaran mengenai ekonomi dan keuangan sedangkan mahasiswa dari program studi berbasis non ekonomi tidak.

Hipotesis kedua yaitu tentang perbedaan tingkat perilaku keuangan mahasiswa, hipotesis pertama $H_{0}$ : Tidak terdapat perbedaan tingkat perilaku keuangan mahasiswa program studi berbasis ekonomi dan non ekonomi. Lalu, $\mathrm{H}_{2}$ : Terdapat perbedaan tingkat perilaku keuangan mahasiswa program studi berbasis ekonomi dan non ekonomi. Hasil pengujian ditunjukkan pada Tabel 6 dimana tabel tersebut menunjukkan nilai signifikansi 0,407 > 0,005 hal ini menunjukkan tidak terdapat perbedaan tingkat perilaku keuangan mahasiswa program studi berbasis ekonomi dan non ekonomi.

Tabel 6. Hasil Uji Hipotesis

\begin{tabular}{|l|l|l|}
\hline Hipotesis & Signifikansi & Keputusan \\
\hline $\begin{array}{l}\text { Terdapat perbedaan tingkat literasi keuangan } \\
\text { mahasiswa program studi berbasis ekonomi } \\
\text { dan non ekonomi }\end{array}$ & 0,002 & Hipotesis diterima \\
\hline $\begin{array}{l}\text { Terdapat perbedaan tingkat perilaku keuangan } \\
\text { mahasiswa program studi berbasis ekonomi } \\
\text { dan non ekonomi }\end{array}$ & 0,407 & Hipotesis ditolak \\
\hline
\end{tabular}

Sumber: Hasil Penelitian, diolah (2018)

\section{KESIMPULAN DAN SARAN \\ Kesimpulan}

Berdasarkan hasil penelitian yang telah dilakukan didapatkan kesimpulan sebagai berikut:

1. Berdasarkan hasil Uji Mann Whitney, nilai Asymp. Sig. (2-tailed) adalah 0,002 yang berarti bahwa nilai Asymp. Sig. tersebut < nilai signifikansi yaitu 0,05. Maka dapat disimpulkan bahwa $\mathrm{H}_{0}$ ditolak atau terdapat perbedaan yang signifikan antara literasi keuangan mahasiswa dari program studi berbas is ekonomi dan non ekonomi.

2. Berdasarkan hasil Uji Mann Whitney, nilai Asymp. Sig. (2-tailed) adalah 0,407 yang berarti bahwa nilai Asymp. Sig. tersebut > nilai signifikansi yaitu 0,05. Maka dapat disimpulkan bahwa $\mathrm{H}_{0}$ diterima atau tidak terdapat perbedaan yang signifikan antara perilaku keuangan mahasiswa dari program studi berbasis ekonomi dan non ekonomi.

\section{Saran}

Berdasarkan hasil penelitian, pembahasan dan kesimpulan yang dikemukakan, maka penulis memberikan beberapa saran yang diharapkan dapat dijadikan masukan dan memperluas pengetahuan, antara lain:

1. Saran Bagi Penelitian Selanjutnya

Penelitian dapat dikembangkan tidak hanya dilakukan di Universitas Telkom tetapi dapat dilakukan di seluruh Universitas di Kota Bandung atau kota lainnya. 
2. Saran Bagi Pihak Universitas

Bagi Universitas Telkom untuk secara aktif memberikan pendidikan mengenai keuangan tidak hanya untuk mahasiswa program studi berbasis ekonomi namun non ekonomi juga, serta mendorong seluruh mahasiswa untuk memiliki perilaku keuangan yang positif.

3. Saran Bagi Lembaga Keuangan

Bagi Lembaga keuangan agar turut berperan dalam memberikan pendidikan keuangan kepada masyarakat khususnya mahasiswa agar mempunyai pengetahuan mengenai keuangan yang cukup yang bisa meningkatkan literasi keuangannya.

4. Saran Bagi Mahasiswa

Bagi mahasiswa untuk tetap belajar dan peka terhadap informasi mengenai keuangan dan sangat penting untuk mengembangkan kebiasaan perilaku keuangan yang positif.

\section{DAFTAR PUSTAKA}

CNN Indonesia. 2018. Alasan Generasi Milenial Lebih Konsumtif. Tersedia di https://www.cnnindonesia.com/gaya-hidup/20180418215055-282-291845/alasangenerasi-milenial-lebih-konsumtif

Dewi, R. K. 2017. Risiko dalam Manajemen Usaha Tani. DIKTAT Univesitas Udayana.

Horovitz, B. 2012. After Gen X, Millenial, what should next generation be?. Tersedia di https://usatoday30.usatoday.com/money/advertising/story/2012-05-03/namingthe-next-generation/54737518/1

Kata Data. 2018. 2018, Jumlah Penduduk Indonesia Mencapai 265 Juta Jiwa. Tersedia di https://databoks.katadata.co.id/datapublish/2018/05/18/2018-jumlahpenduduk-indonesia-mencapai-265-juta-jiwa

Kholilah, N., dan Iramani, Rr. 2013. Studi Financial Management Behavior Pada Masyarakat Surabaya. Journal of Business and Bangking, 3(3), 69-80

Laily, Nujmatul. 2013. Pengaruh Literasi Keuangan Terhadap Perilaku Mahsiswa dalam Mengelola Keuangan. Jurnal Elektronik Universitas Negeri Malang, 1(4)

Lestari, Sri. 2015. Literasi Keuangan Serta Penggunaan Produk dan Jasa Lembaga Keuangan. Jurnal Fokus Bisnis, 14(2), 14-24.

Lusardi, A. dan Mitchell, O. The Economic Importance of Financial Literac: Theori and Evidence. Journal of Economic Literature, 52(1), 5-44.

Margaretha, F. dan Pambudhi, R. A. 2015. Tingkat Literasi Keuangan Pada Mahasiswa S-1 Fakultas Ekonomi. Jurnal Manajemen dan Kewirausahaan, 17(1), 76-85.

Nababan, S., dan Isfenti, S. 2013. Analisis Personal Financial Literacy dan Financial Behavior Mahasiswa Strata I Fakultas Ekonomi Universitas Sumatera Utara. Jurnal Media Informasi Manajemen. 1(1), 1-15.

Otoritas Jasa Keuangan. 2017. Strategi Nasional Literasi Keuangan Indonesia (Revisit 2017). Jakarta: Otoritas Jasa Keuangan.

Sari, D. A., 2015. Financial Literacy dan Perilaku Keuangan Mahasiswa (Studi Kasus Mahasiswa STIE 'YPPI' Rembang). Buletin Bisnis dan Manajemen, 1(2),171-189 
Solihat, Nur dan Anarsik, S. 2018. Pengaruh Literasi Ekonomi Terhadap Perilaku Konsumtif Mahasiswa Jurusan Pendidikan Ekonomi Universitas Siliwanngi. Jurnal Kajian Pendidikan Ekonomi dan Ilmu Ekonomi, 2(1), 1-13

VISA. 2012. Visa's International Financial Literacy. Tersedia di http://www.africamoneyskills.com/downloads/FL_Barometer_Final\%20Apr\%20 2012.pdf

Yushita, Amanita Novi. 2017. Pentingnya Literasi Keuangan Bagi Pengelolaan Keuangan Pribadi. Jurnal Nominal, 5(1), 11-26.

Walidah, Iffah. 2017. Tabayyun di Era Genrasi Millenial. Jurnal Living Hadis, 2(1), 317-344

Widayati, I. 2012. Faktor-Faktor yang Mempengaruhi Literasi Finansial Mahasiswa Fakultas Ekonomi dan Bisnis Universitas Brawijaya. ASSET: Jurnal Akuntansi dan Pendidikan, 1(1), 89-99. 